will provide assistance to any teacher-training school requesting it, and will work in close co-operation with representatives of Catholic and Protestant educational authorities in the Congo and with the University of Lovanium.

\title{
Afro-Asian Studies in the University of Cambridge
}

THE University of Cambridge has established a group for Afro-Asian Social Studies with a documentation centre and a seminar room. The centre contains recent reports on economic, political, and social questions and a bibliography arranged under regions and subjects. Research programmes and inter-disciplinary seminars are being organized. In October I $96 \mathrm{I}$ a post-graduate seminar was started on 'Elite Formation in Emergent States' held by Dr. E. Shils and Dr. A. I. Richards. From January 1962 there will be seminars on 'The Productivity of Peasant Agriculture', held by Professor Sir Joseph Hutchinson and Mr. Leonard Joy, and 'Economic Enclaves in Under-Developed Countries', held by Professor E. A. G. Robinson and Miss Phyllis Deane. The Inter-Disciplinary Seminar on African Problems, which has been held in Cambridge for the past two years, will also be attached to the centre. Inquiries on the documentation centre should be addressed to the Librarian, Miss Julia Allen, Afro-Asian Group, Faculty of Economics, Sidgwick Avenue, Cambridge. Inquiries on the programme of the group should be made to Mr. Kenneth Berrill at the same address.

\section{Sorbonne - Ecole Pratique des Hautes Etudes (VIe Section): Initiation à la recherche africaniste}

UN enseignement d'initiation à la recherche africaniste fonctionnera au cours de l'année universitaire 1961-2 à l'École Pratique des Hautes Études, section des sciences économiques et sociales. Il est principalement destiné aux étudiants inscrits en première année du $3^{\circ}$ Cycle de l'Enseignement Supérieur et dont les travaux exigeront une connaissance d'ensemble des problèmes spécifiques de la recherche en Afrique Noire.

Cet enseignement est ouvert aux étudiants de toutes disciplines, quelle que soit la Faculté ou l'Institution d'Enseignement Supérieur dans laquelle ils auront pris leur inscription. Il est obligatoire pour les étudiants qui prendront cette inscription à l'École Pratique des Hautes Études, section des sciences économiques et sociales (Centre d’Études Africaines).

Le programme d'étude s'étendra du I er décembre I96I au I ${ }^{\text {er }}$ juin I962. Il comprendra des cours de préparation à la recherche, des travaux pratiques, des séminaires consacrés à des études de cas, organisés dans chacune des disciplines africanistes suivantes: géographie humaine, histoire, linguistique afticaine, ethnologie générale, ethnologie politique, ethnologie économique.

Ce cycle entre dans sa deuxième année. En 1960-I il a groupé une trentaine d'étudiants dont deux-tiers environ de Français.

\section{A Russian Ethnographic Map of Africa}

An ethnographic map, Karta Narodov Afriki (Map of the Peoples of Africa), has recently been published by the Institut Etnografii in Moscow. The map is in two sheets, divided along the equator, and on a scale of $\mathrm{I}: 8,000,000$. Ethnic groups are distinguished by colours, and eight population densities by shading. Areas of mixed population are indicated in four differing ratios. Numerals locate particular peoples given in the key, as only major ethnic groups are named on the map. Rivers and towns are shown but not contours. Political and administrative boundaries are as at the end of 1960. 